\title{
King of the Birds! The changing role of white-tailed (Haliaeetus albicilla) and golden-eagles (Aquila chrysaetos) in Britain's past
}

\author{
MATILDA HOLMES \\ Institute of Archaeology, University College London, \\ 31-34 Gordon Square, London, WC1H OPY \\ matty@archaeozoology.co.uk
}

(Received 13 September2017; Revised 2 November 2017; Accepted 1 January 2018)

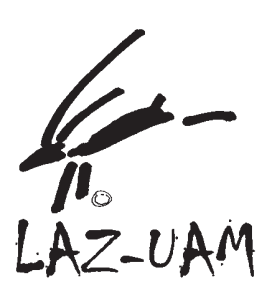

ABSTRACT: Bones of white-tailed and golden eagles from 58 British archaeological sites occupied from the Mesolithic to medieval periods are considered in terms of their various and changing roles, using zooarchaeological, contextual, documentary and ethnographic sources. Evidence is presented that implies the changing cultural and social importance of these birds such as their exploitation by coastal populations, as Bronze Age talismans, targets for Iron Age and Roman feather collectors, and exhibition within medieval mews. The relationships between eagles and humans are also considered based on long-standing, recurring and cross-cultural perceptions.

KEYWORDS: WHITE-TAILED EAGLE, GOLDEN EAGLE, ZOOARCHAEOLOGY, BRITAIN

RESUMEN: El trabajo valora restos de Águila Real y Pigargo de 58 yacimientos arqueológicos británicos que cubren desde el Mesolítico a época medieval desde la perspectiva de los variados y cambiantes roles de estos animales utilizando fuentes zooarqueológicas, contextuales, documentarias y etnográficas. Se presenta evidencia que revela la cambiante importancia cultural y social de ambas aves. Ello incluye su explotación por parte de las poblaciones costeras como talismanes en la Edad del Bronce por sus plumas en la Edad del Hierro y romana y como animales de exhibición en las ferias medievales. Las relaciones entre las águilas y los humanos se valoran también sobre la base de percepciones recurrentes y duraderas a través de distintas culturas.

PALABRAS CLAVE: PIGARGO, ÁGUILA REAL, ZOOARQUEOLOGÍA, BRETAÑA 


\section{INTRODUCTION}

Britain has two indigenous eagles, the whitetailed eagle, Haliaeetus albicilla (Figure 1) and golden eagle, Aquila chrysaetos (Figure 2). Previous work has considered eagles in terms of place name evidence (Gelling, 1987; Yalden, 2002; Watson, 2010), isolated finds (Baxter, 1993a; Durham, 2013) and within wider place- or period-specific archaeological studies [for example, Best \& Mulville, Forthcoming; Parker (1988), Mulkeen \& O'Connor (1997), Serjeantson (2010)]. This paper provides the first comprehensive and focused survey of eagle remains from British archaeological sites from the Mesolithic to medieval periods. Factors such as their depositional context and associated faunal remains will be considered to elucidate their role in past societies, specifically regarding the following research questions:

1. What is the nature of eagle remains within the archaeological record? What type of sites are they found at and in what numbers?

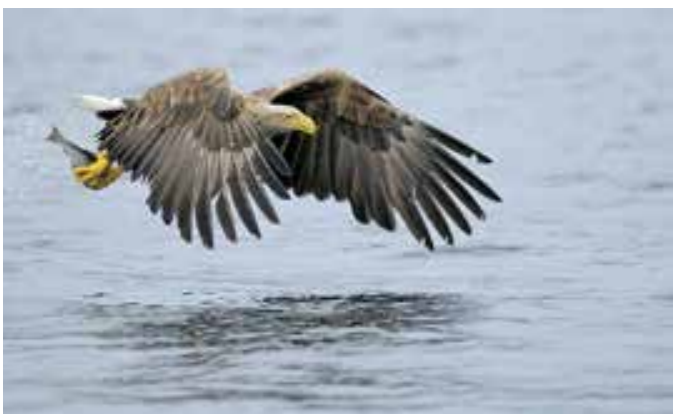

FIGURE 1

White-tailed eagle. Photo copyright of Vittorio Ricci.

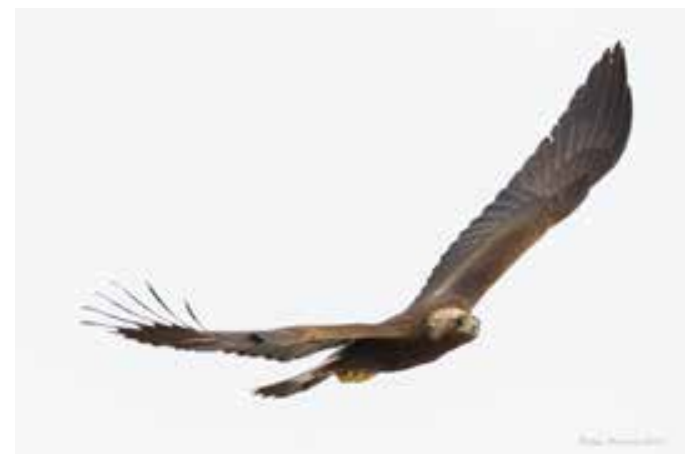

FIGURE 2

Golden eagle. Photo copyright of Amy Hudechek.
2. What is the nature of their deposition? Do the contexts in which they occur imply general refuse disposal or are they subject to more deliberate placements? What other animals are they found with?

3. Do eagle remains represent culturally symbolic roles, economic uses or incidental inclusions in the archaeological record? Can inferences be made about the nature of human and eagle relationships?

\section{ECOLOGY AND PAST DISTRIBUTIONS}

The ecological habitats of the two birds are distinct - today the white-tailed eagle prefers open water in lowland areas, nesting in areas ranging from intensively farmed land to woods to towns, while the golden eagle tends to be confined to the uplands (Hardey, 2006: 81; Watson, 2010: 49; Evans et al., 2012: 338; Serjeantson, pers com). This led Yalden $(2002,2007)$ to infer that most place names containing earn, the Old English name for eagles, were more likely to refer to white-tailed eagles, as they coincided with woodland elements rather than cliffs or hills (ibid 2002: 417). The association of the white-tailed eagle with settlement names is mirrored by the abundance of this taxon over the golden eagle in the archaeological record (Figure 3). This may not be coincidental, as the favourable siting of settlements in lowland areas close to a source of water and fuel would be more likely to bring people and white-tailed eagles into contact with each other rather than the inhospitable upland areas favoured by the golden eagle (Yalden \& Albarella, 2009: 124). Also of note is the proliferation of eagle place names. They are the second most common bird-related name in England after those referring to crane, with 53 sites deriving from the root earn (Gelling, 1987), a number that rises to 537 if place names from Ireland, Wales and Scotland are taken into account (Evans et al., 2012). The nature of these birds as top predators, combined with their size (the wingspan of the golden eagle is up to $2 \mathrm{~m}$, and that of the white-tailed eagle $2.4 \mathrm{~m}$ ) makes it understandable that if eagles featured in the landscape, they would be included when naming a settlement or place.

The diet of the white-tailed eagle includes fish, deer, lambs, rabbits, hares and birds from gulls to geese, while golden eagles will eat small mammals 

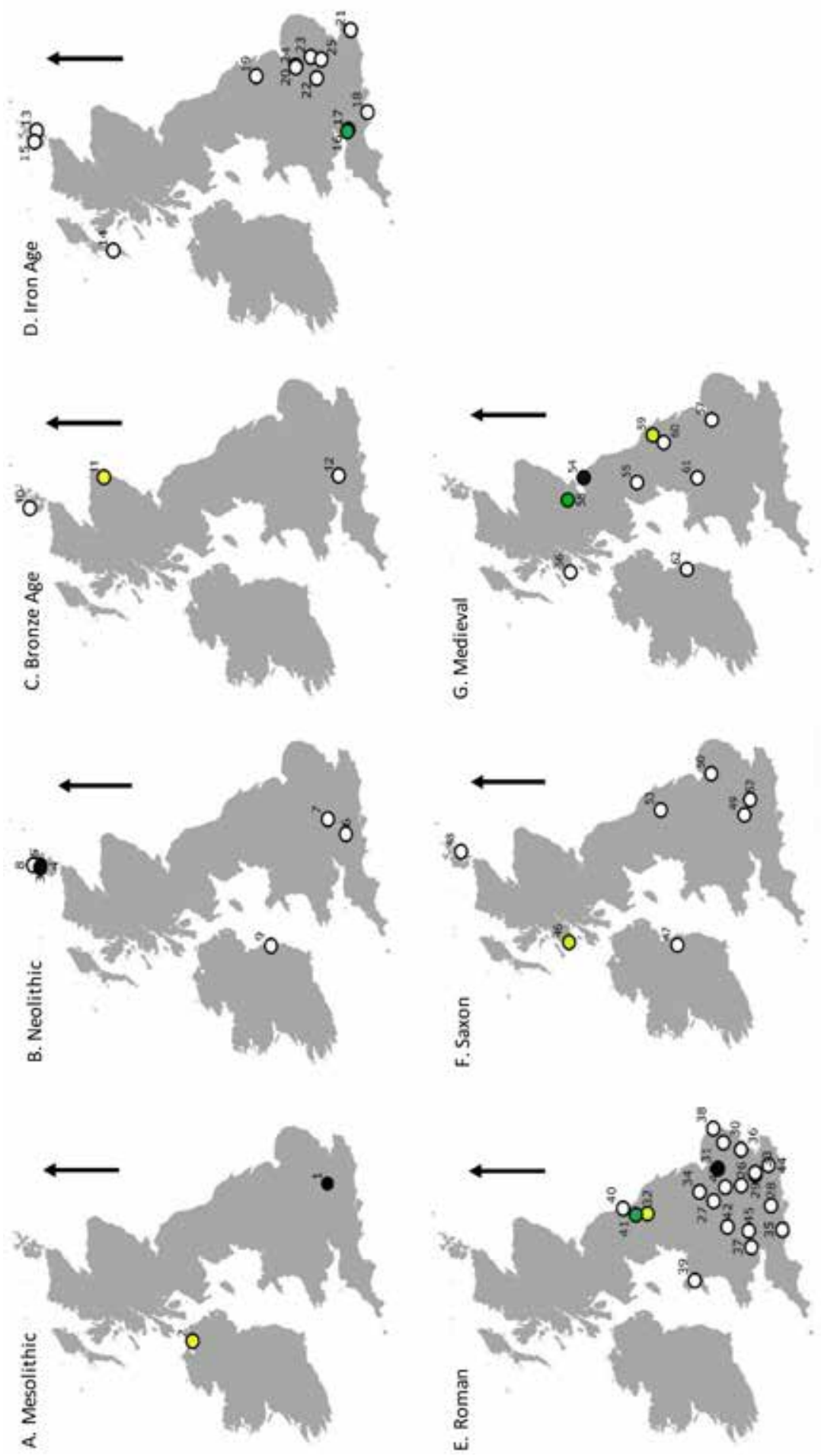

FIGURE 3

Location of eagle finds referred to in the text. Yellow circle= golden eagle; white $=$ white tailed eagle; green= both; black= eagle . Site numbers given in Table 1. 
such as hares and rabbits and similar-sized birds such as grouse. Both species are also scavengers and will eat carcasses of sheep and deer if available. Today farmers in some areas of Scotland are compensated for livestock killed by white-tailed eagles, but in the past it was a problem that was practically remedied by culling. The popularisation of shooting as a country pursuit in the $19^{\text {th }}$ century meant that gamekeepers increasingly killed birds of prey to protect their game birds. Between 1837 and 1840 gamekeepers on the Glengarry Estate in the Scottish highlands killed 27 white-tailed eagles and 15 golden eagles (Hart-Davis, 2002: 264). It comes as no surprise then, that by the end of the $19^{\text {th }}$ century their distribution had greatly diminished, being restricted to areas of Scotland and Ireland (Evans et al., 2012: figure 2). By 1918 the last white-tailed eagle in Britain was killed, while golden eagles were able to live in low numbers, sheltering in Scottish deer forests (Serjeantson, 2010: 152; Evans et al., 2012: 342).

\section{METHODS}

A search of documented eagle remains from Mesolithic to medieval periods was undertaken. While the bones of white-tailed eagle and golden eagle are relatively easy to discern morphologically with the aid of reference material, not all the specimens included in the survey could be distinguished due to issues relating to fragmentation, preservation, or the absence of comparative material. Some were detailed in previous ornithological works (e.g. Yalden, 2007; Yalden \& Albarella, 2009), others came regional reviews (Albarella \& Pirnie, 2008; Hambleton, 2008; Serjeantson, 2011; Holmes, 2014; Allen et al., 2015; Holmes, forthcoming) and others from a trawl of published and unpublished reports. As much information as possible was recorded, including identification, burial context, anatomical element, modifications and the interpretation given by the author at the time. Only remains from archaeological sites were included, finds resulting from nesting sites were omitted. Some of the more detailed reports are targeted as case studies, incorporating data relating to other bird taxa and the nature of the settlement. Dating of the major periods was taken from the National Monument record thesaurus (English Heritage, 1999). A list of common and Latin names of animals referred to in the text is given in Appendix 1.

\section{EAGLES IN BRITAIN'S PAST}

Eagles are present in all periods, generally in low numbers (Figure 3; Table 1), of which the white-tailed eagle is the most commonly recorded. There is a considerable increase in the number of

so

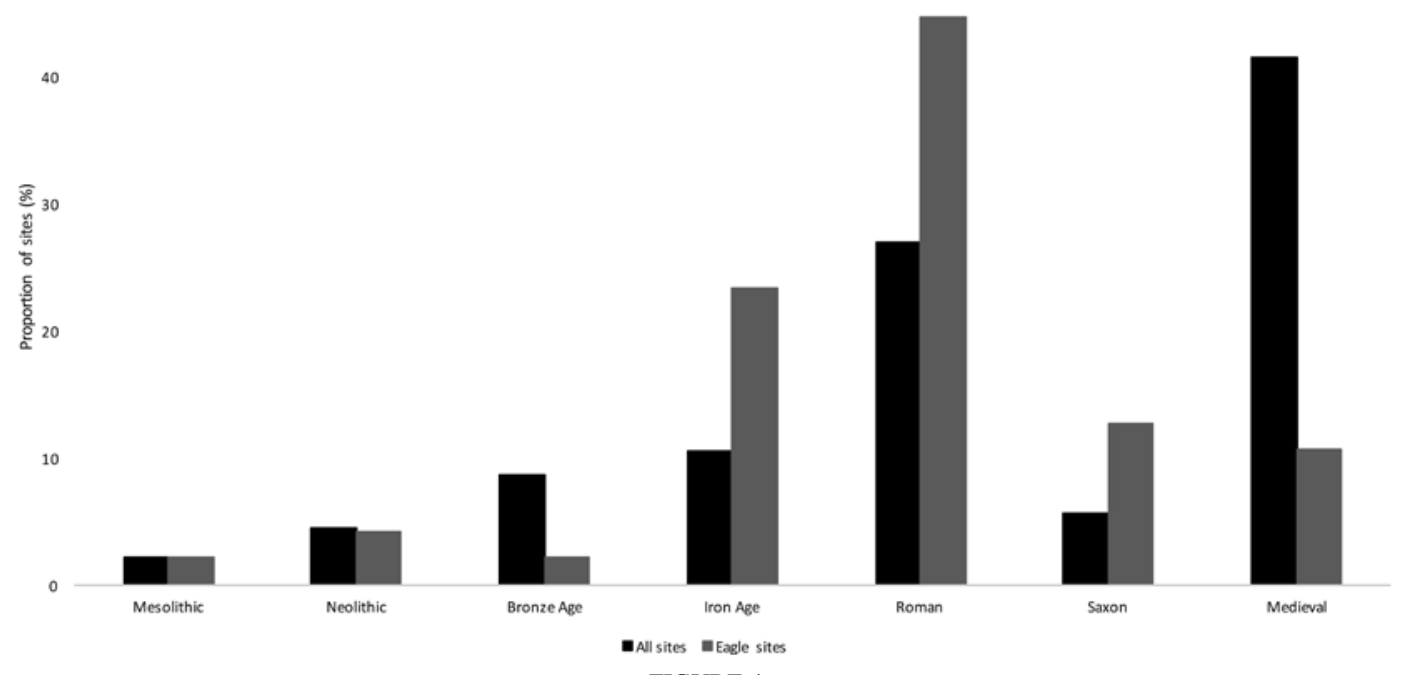

FIGURE 4

Proportion of English sites containing eagle remains by period compared with total number of field evaluations carried out in England between 1982 and 2010 (data from Archaeological Investigations Project) 
sites represented in the Iron Age and Roman periods. The extent to which this is a product of the frequency of excavated sites was considered by comparing the proportion of field investigations (excavations/ watching briefs/ evaluations) carried out on sites of each period between 1982 and 2010 (Bournemouth University 2012) with the proportion of sites in England with eagle remains in the data set (Figure 4). Although this is a rather blunt tool, results indicate that a high proportion of eagle remains in the Iron Age, Roman and Saxon periods may be due to deliberate collection, while the reverse is true in the Bronze Age and medieval periods. With this in mind, the results from the survey will be described by phase, and more nuanced explanations considered.

The propensity for eagle remains to come from sites in the east and south of Britain until the medieval period (Figure 3) is not consistent with their reconstructed distribution at around AD 500, which implies a more even dispersal with a particular emphasis on the south, midlands and north of England, most of Scotland and coastal areas of Ireland (Evans et al., 2012: 342, fig 3a). There are two possibilities for this discrepancy. The first concerns the natural geology of the country and the effect of more acidic soils on the preservation of animal bone. This means that much of Wales, Scotland and the south-west, south-east and north-west of England, are less likely to produce well-preserved animal bone assemblages than eastern Ireland and south-central and midland England (Baker \& Worley, 2014: 3). This is a highly likely explanation for the findings of eagle remains in these areas, although the second possibility, that there are culturally-specific reasons for eagles to be found in these areas (particularly in the Iron Age and Roman periods), will be explored further below.

\section{MESOLITHIC (10000-4000 BC)}

Eagle bones were recovered from two Mesolithic camps (Table 1 and Figure 3A). The eagle long bone from Three Ways Wharf, Uxbridge was found alongside a group of flint tools and the bones of horse and reindeer at a probable hunting camp, with no explanation of the possible relationship between them, if indeed one was discernible. The camp at Mount Sandel provided the bone of a golden eagle from a pit containing wild boar remains as well as red-throated diver and grouse (Table 2). The implication at this site is one of direct contact between people and eagles. This is a vastly diverse and varied period of time (Spikins, 2008) and the spatial and contextual differences between the two sites negate any meaningful links.

\section{NEOLITHIC (4000-2200BC)}

Four of the seven sites producing eagle bones in the Neolithic come from Orkney (Table 1 and Figure 3B), of which three are tombs. The large number of white-tailed eagle bones from the renowned 'Tomb of the Sea Eagles' at Isbister are included in the Bronze Age discussion, following revised dating evidence placing them as inclusions one thousand years after the original use of the tomb (Pitts, 2006; Serjeantson, 2009: 360). It is possible that the eagles within the tombs from the Knowe of Ramsey, Point of Cott and Midhowe were similarly later additions. Nonetheless, their presence alongside humans implies a strong connection between the dead and these birds, which will be considered further in the next section.

The white-tailed eagle from the Links of Notland, Orkney came from a specific blocking deposit alongside two cattle skulls, which has been described as a ritual undertaken to define re-use of the building (Jones, 1998: 316). The diversity of wild bird taxa recovered from the same settlement (Table 2) is unusual at a time when the widespread exploitation of wild resources ceases throughout Britain (Schulting \& Richards, 2002; Serjeantson, 2014). The find at the settlement on Dalkey Island, County Dublin was also made alongside wild bird remains, although fewer than at the Links of Notland. Serjeantson has suggested that evidence for hunting in the Neolithic should be viewed as ceremonial, creating links with the past way of life, maybe as a rite of passage (Serjeantson, 2011: 52). However, the presence of relatively high proportions of wild taxa in more domestic settings at coastal sites rather imply that some marginal populations in the Neolithic were slower to give up local produce, which is reflected in occasional findings from isotope analysis of human remains (Schulting \& Richards, 2002: 174).

Where eagle remains exist on the mainland in the British Isles they tend to be as isolated finds. A white-tailed eagle partial skeleton from Coneybury 


\begin{tabular}{|c|c|c|c|c|c|c|}
\hline $\mathbf{N}$ & Period/ Site Name & Taxa & Site Type & Reference & Context & Element and comments \\
\hline & Mesolithic & & & & & \\
\hline 1 & $\begin{array}{l}\text { Three Ways Wharf, Uxbridge, } \\
\text { London }\end{array}$ & EAGLE & Camp & $\begin{array}{l}\text { Thompson et al } \\
1998\end{array}$ & & 1 bone \\
\hline \multirow[t]{2}{*}{2} & $\begin{array}{l}\text { Mount Sandel, County London- } \\
\text { derry }\end{array}$ & GE & Camp/ settlement & \begin{tabular}{|l} 
van Wijngaar- \\
den-Bakker 1985
\end{tabular} & Pit & \\
\hline & Neolithic & & & & & \\
\hline 3 & Midhowe, Orkney & EAGLE & Tomb & $\begin{array}{l}\text { Davidson \& Hens- } \\
\text { hall } 1989\end{array}$ & Tomb & \\
\hline 4 & Knowe of Ramsey, Orkney & WTE & Tomb & Platt 1936 & Tomb & Coracoid \\
\hline 5 & Point of Cott, Westray & WTE & Tomb & Harman 1997 & Cairn & MNI 8 partial skeles \\
\hline 6 & Coneybury Henge, Wiltshire & WTE & Henge & Maltby 1990 & Ditch & $\begin{array}{l}\text { Left wing bones and verte- } \\
\text { brae (pathology) }\end{array}$ \\
\hline 7 & Barrow Hills, Radley, Oxfordshire & WTE & Pit cluster & $\begin{array}{l}\text { Levitan and Ser- } \\
\text { jeantson } 1999\end{array}$ & Pit & Ulna (worked) \\
\hline 8 & Links of Notland, Orkney & WTE & Settlement & Armour-Chelu 1988 & Blocking deposit & 1 bird \\
\hline \multirow[t]{2}{*}{9} & Dalkey Island, Co. Dublin & WTE & Midden & Hatting 1968 & Midden & $\begin{array}{l}\text { Carpometacarpal, femur and } \\
\text { tarsometatarsal }\end{array}$ \\
\hline & Bronze Age & & & & & \\
\hline 10 & Isbister, Orkney & WTE & Tomb & Bramwell, 1983 & Tomb & $\begin{array}{l}\text { MNI } 7 \text { plus large number } \\
\text { 3rd phalanges }\end{array}$ \\
\hline 11 & Skilmafilly, Aberdeenshire & GE & Cemetery & Smith, 2012 & Child cremation & $\begin{array}{l}\text { 2nd phalanx, 2x3rd phalan- } \\
\text { ges (in bag?) }\end{array}$ \\
\hline \multirow[t]{2}{*}{12} & Potterne, Wiltshire & WTE & Settlement & Locker 2000 & Off terrace & 3rd phalanx (perforated) \\
\hline & Iron Age & & & & & \\
\hline 13 & Skaill, Deerness, Orkney & WTE & Settlement & Allison 1997 & & 2 bones \\
\hline 14 & Cladh Hallan, South Uist & WTE & Settlement & \begin{tabular}{|l} 
Best and Mulville \\
2013
\end{tabular} & Roundhouse & 3rd phalanx \\
\hline 15 & Howe, Orkney & WTE & Settlement & Bramwell, 1994 & & \\
\hline 16 & Meare Lake Village, Somerset & WTE + GE & Settlement & $\begin{array}{l}\text { Gray \& Cotton } \\
1966\end{array}$ & Mounds & $\begin{array}{l}\text { 3xphalanges of WTE, GE } \\
\text { not specified }\end{array}$ \\
\hline 17 & $\begin{array}{l}\text { Glastonbury Lake Village, } \\
\text { Somerset }\end{array}$ & WTE & Settlement & Andrews 1917 & & \\
\hline 18 & Ower, Purbeck & WTE & Settlement & Coy, 1987 & & \\
\hline 19 & Dragonby, Lincolnshire & WTE & Settlement & Harman, 1996 & Ditch and pit & 2 ABGs + other bones \\
\hline 20 & Cat's Water, Fengate, Peterborough & WTE & Settlement & $\begin{array}{l}\text { from Yalden and } \\
\text { Albarella } 2009\end{array}$ & & \\
\hline 21 & Cheriton Rd, Folkestone, Kent & WTE & Settlement & Holmes 2016 & Pit & Ulna and radius (butchered) \\
\hline 22 & Fenny Lock, Milton Keynes & WTE & Settlement & Ford et al 2001 & Pit & Humerus (butchered) \\
\hline 23 & $\begin{array}{l}\text { Trumpington Meadows, Cambri- } \\
\text { dgeshire }\end{array}$ & WTE & Settlement & $\begin{array}{l}\text { Rajkovaca forth- } \\
\text { coming }\end{array}$ & & \\
\hline 24 & Longthorpe, Cambridgeshire & WTE & Fort & King, 1987 & Ditch & Femur \\
\hline \multirow[t]{2}{*}{25} & $\begin{array}{l}\text { Puckeridge and Braughing 75-9, } \\
\text { Hertfordshire }\end{array}$ & WTE & oppida & Ashdown 1979 & Layer & $\begin{array}{l}\text { Coracoid and humerus } \\
\text { (butchered) }\end{array}$ \\
\hline & Roman & & & & & \\
\hline 26 & Dunstable, Bedfordshire & WTE & Urban & $\begin{array}{l}\text { Jones and Horne } \\
1981\end{array}$ & Cesspit & Skeleton \\
\hline 27 & High St, Leicester & WTE & Urban & Baxter 1993a & Well & Skull (decapitated) \\
\hline 28 & Northern Suburbs, Winchester & WTE & Urban & Maltby 2010 & Pit & Humerus \\
\hline 29 & 8 Union St, Southwark, London & WTE & Urban & Cowles 1980 & Well & Femur and coracoid \\
\hline 30 & Scole-Dickleburgh, Norfolk & WTE & Urban & Baker 1998 & Pit & Femur \\
\hline 31 & Stonea, Cambridgeshire & EAGLE & Settlement & Stallibrass 1996 & & \\
\hline 32 & $\begin{array}{l}\text { Bainesse (Site 46), Catterick, } \\
\text { Yorkshire }\end{array}$ & GE & Settlement & Meddens 2002 & & 1 bone \\
\hline 33 & Billingsgate Buildings, London & WTE & Settlement & Cowles 1980 & & 1 bone \\
\hline 34 & $\begin{array}{l}\text { Pasture Lodge Farm, Long Bennin- } \\
\text { gton, Lincolnshire }\end{array}$ & WTE & Settlement & Harman 1994 & & Mandible \\
\hline 35 & Tolpuddle Ball, Dorset & WTE & Settlement & $\begin{array}{l}\text { Hamilton-Dyer } \\
1999\end{array}$ & Layer & 1 bone (female) \\
\hline 36 & Sheepen, Colchester, Essex & WTE & Fort & Luff, 1985 & Postpit & $2 \mathrm{x}$ birds \\
\hline
\end{tabular}




\begin{tabular}{|c|c|c|c|c|c|c|}
\hline \multicolumn{7}{|c|}{ Table 1. Continuated } \\
\hline 37 & Caerleon, Newport, Wales & WTE & Fort & $\begin{array}{l}\text { Hamilton-Dyer } \\
1993\end{array}$ & Well & 3 bones (immature) \\
\hline 38 & Caister-on-sea, Norfolk & WTE & Fort & Harman 1993 & Drain & \\
\hline 39 & Segontium, Gwynedd & WTE & Fort & O'Connor 1993 & & $\begin{array}{l}\text { 3x tibiotarsae, } 2 x \text { coracoids, } \\
\text { scapula }\end{array}$ \\
\hline 40 & South Shields, Newcastle & WTE & Fort & Stokes 2000 & House and garrison & MAU 14 birds \\
\hline 41 & Binchester, Co Durham & WTE + GE & Fort & $\begin{array}{l}\text { Cussons and Bond } \\
2010\end{array}$ & Layer & $\begin{array}{l}41 \text { WTE bones nearly all } \\
\text { wings (butchered); 3x GE } \\
\text { radius }\end{array}$ \\
\hline 42 & $\begin{array}{l}\text { Bays Meadow Villa, Droitwich, } \\
\text { Worcestershire }\end{array}$ & WTE & Villa & Bramwell 2006 & & 2 femurs and other bones \\
\hline 43 & $\begin{array}{l}\text { Redlands Farm, Stanwick, Nor- } \\
\text { thamptonshire }\end{array}$ & WTE & Villa & Davis 1997 & & Tarsometatarsal and ?ulna \\
\hline 44 & Springhead, Kent & prob WTE & Temple & Grimm 2011 & Shaft & \\
\hline \multirow[t]{2}{*}{45} & Uley Shrines, Gloucestershire & WTE & Shrine & Levitan 1993 & pre building $\mathrm{X}$ & \\
\hline & Saxon & & & & & \\
\hline 46 & Iona, Argyl & GE & Monastic & \begin{tabular}{|l|} 
Bramwell 1981; \\
Coy and Hamil- \\
ton-Dyer 1993 \\
\end{tabular} & Midden & Metacarpal (weathered) \\
\hline 47 & Lagore, Ratoath & WTE & Crannog & Stelfox 1938 & Midden & 4 bones \\
\hline 48 & Skaill, Deerness, Orkney & WTE & Settlement & Allison 1997 & & 1 bone \\
\hline 49 & Barton Court Farm & WTE & Settlement & Wilson et al. 1986 & $\begin{array}{l}\text { Sunken feature } \\
\text { building }\end{array}$ & 2 frags \\
\hline 50 & Crow hall park, Downham Market & WTE & Settlement & Curl 2008 & & \\
\hline 51 & Lake End Rd, Berkshire & WTE & Trading site & $\begin{array}{l}\text { Powell and Clark } \\
2002\end{array}$ & & tibiotarsus (butchered) \\
\hline 52 & Lot's Hole, Berkshire & WTE & Trading site & $\begin{array}{l}\text { Powell and Clark } \\
2002\end{array}$ & & 3rd phalanx \\
\hline \multirow[t]{2}{*}{53} & York Minster & WTE & Urban & Rackham 1995 & Layer & 1 bone \\
\hline & Medieval & & & & & \\
\hline 54 & Castle Park, Dunbar, East Lothian & EAGLE & Castle & Smith 2000 & & 1 bone \\
\hline 55 & Brougham Castle, Cumbria & WTE & Castle & Gidney 1992 & & \\
\hline 56 & Iona, Argyl & WTE & Abbey & \begin{tabular}{|l|}
$\begin{array}{l}\text { Coy and Hamil- } \\
\text { ton-Dyer } 1993\end{array}$ \\
\end{tabular} & Midden & Beak and others \\
\hline 57 & $\begin{array}{l}\text { Anchor Church, Crowland, } \\
\text { Lincolnshire }\end{array}$ & WTE & Chapel & Holmes 2004 & Dark earth layer & $\begin{array}{l}\text { Coracoid, humerus, tibiotar- } \\
\text { sus, tarsometatarsal }\end{array}$ \\
\hline 58 & High St, Perth & EAGLE & Urban & Smith 1997 & Midden & 1 bone \\
\hline 59 & Hungate, York & GE & Urban & \begin{tabular}{|l|} 
Rainsford et al \\
2016 \\
\end{tabular} & Cesspit & Humerus \\
\hline 60 & Coppergate, York & WTE & Urban & O'Connor 1989 & & 4 of 6 bones from wing \\
\hline 61 & $\begin{array}{l}\text { Crown Car Park, Nantwich, } \\
\text { Cheshire }\end{array}$ & WTE & Urban & Fisher 1986 & Ditch & \begin{tabular}{|l|}
$\begin{array}{l}\text { Carpometacarpal and radius } \\
\text { (pathology) }\end{array}$ \\
\end{tabular} \\
\hline 62 & Wood Quay, Dublin & WTE & Urban & \begin{tabular}{|l|} 
from Yalden and \\
Albarella 2009 \\
\end{tabular} & & \\
\hline 63 & Perth High St, Perth & WTE + GE & Urban & $\begin{array}{l}\text { Smith and Clarke } \\
2011\end{array}$ & & 3 bones GE; 2 bones WTE \\
\hline
\end{tabular}

TABLE 1

Details of eagle finds from Britain and Ireland as described in the site report. * Scottish Christian and Viking periods and the Irish early historic period correspond to the English Saxon period. $\mathrm{N}=$ site number; WTE $=$ white-tailed eagle; $\mathrm{GE}=$ golden eagle; $\mathrm{MNI}=$ minimum number of individuals; $\mathrm{ABG}=$ associated bone group; $\mathrm{MAU}=$ minimum animal unit.

Henge came from a likely symbolic deposit, buried together with a male dog in the primary fill of a ditch (Maltby, 1990). The white-tailed eagle ulna from Barrow Hills, Radley presents a more functional role (although perhaps retaining a symbolic quality) where the bone took on use as a raw material, having been worked into a point, perhaps used as an awl (Levitan \& Serjeantson, 1999).
BRONZE AGE (2600-700 BC)

Eagle remains are recovered from disparate areas in the Bronze Age, but all had been modified and/ or appear in symbolically significant contexts (Table 1 and Figure 3C). Recently amended dating places the eagles from the Neolithic tomb at Isbister, Orkney 


\begin{tabular}{|c|c|c|c|c|c|c|c|c|c|c|c|c|}
\hline Period/ Site Name & 气̆ & 言 & ठ্ & 弟 & 劳 & 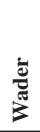 & 吾 & 童 & ن & 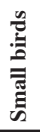 & $\stackrel{\grave{\Xi}}{0}$ & Associated with \\
\hline \multicolumn{13}{|l|}{ Mesolithic } \\
\hline Three Ways Wharf, Uxbridge & $*$ & & & & & & & & & & & $\begin{array}{l}\text { Flint tools and bones of horse and } \\
\text { reindeer }\end{array}$ \\
\hline Mount Sandel, County Londonderry & & & & & & & 1 & & & & 1 & \\
\hline \multicolumn{13}{|l|}{ Neolithic } \\
\hline Midhowe, Orkney & & & & & 4 & & & 1 & 1 & & & \\
\hline Knowe of Ramsey, Orkney & & & $*$ & $*$ & 3 & 2 & 1 & & & & & Human burials \\
\hline Point of Cott, Westray & & & & $*$ & 9 & 2 & & & & 1 & & \\
\hline Coneybury Henge, Wiltshire & & & & & & 1 & & & & & & Partial skeleton of male dog \\
\hline Barrow Hills, Radley, Oxfordshire & $*$ & & & & & & & & & & & \\
\hline Links of Notland, Orkney & & & $*$ & * & 7 & & 2 & 1 & 1 & & & 2 cattle skulls in blocking deposit \\
\hline Dalkey Island, Co. Dublin & & & & $*$ & 2 & & & 1 & & $*$ & & \\
\hline \multicolumn{13}{|l|}{ Bronze Age } \\
\hline Skilmafilly, Aberdeenshire & $*$ & & & & & & & & & & & Child burial \\
\hline Potterne, Wiltshire & & & $*$ & $*$ & 1 & 2 & & 1 & & 1 & & \\
\hline \multicolumn{13}{|l|}{ Iron Age } \\
\hline Skaill, Deerness, Orkney & & $*$ & $*$ & * & 11 & 5 & 2 & 3 & & & 2 & \\
\hline Cladh Hallan, South Uist & & & $*$ & $*$ & 12 & 9 & 3 & 1 & 1 & 2 & 2 & \\
\hline Howe, Orkney & & $*$ & & & 4 & 2 & & 2 & & 1 & & \\
\hline Meare Lake Village, Somerset & & & $*$ & $*$ & 2 & 2 & 1 & 3 & 1 & 1 & & \\
\hline Glastonbury Lake Village, Somerset & & & $*$ & $*$ & 3 & 1 & 3 & 3 & 2 & 1 & & \\
\hline Ower, Purbeck & & $*$ & & $*$ & 1 & 2 & 1 & & & & & \\
\hline Dragonby, Lincolnshire & & $*$ & $*$ & $*$ & & 3 & & 3 & 2 & & & \\
\hline \multicolumn{13}{|l|}{ Cat's Water, Fengate, Peterborough } \\
\hline Cheriton Rd, Folkestone, Kent & & & $*$ & & & & & & & & & \\
\hline Fenny Lock, Milton Keynes & $*$ & & & & & & & & & & & \\
\hline Trumpington Meadows, Cambridgeshire & & $*$ & $*$ & & & & & & 1 & & & \\
\hline Longthorpe, Cambridgeshire & $*$ & & & & & & & & & & & Crane tarsometatarsal butchererd \\
\hline Puckeridge and Braughing 75-9, Hertfordshire & & $*$ & & & & & & & & & & \\
\hline \multicolumn{13}{|l|}{ Roman } \\
\hline Dunstable, Bedfordshire & & & & & & & & & 1 & & & $\begin{array}{l}2 \text { dogs and puppies, other partial mature } \\
\text { and immature skeles, raven and human } \\
\text { baby }\end{array}$ \\
\hline High St, Leicester & & & * & & & & & & 2 & & & $\begin{array}{l}\text { Migrating barnacle goose, } 2 \text { piglets, } \\
\text { kitten, puppy and corvid skeletons }\end{array}$ \\
\hline Northern Suburbs, Winchester & & $*$ & * & $*$ & & 2 & & 1 & 2 & & & $\begin{array}{l}\text { MNI } 8 \text { dog skeletonss, possible cattle } \\
\text { and sheep/ goat skins, raven skeleton, } \\
\text { complete vessels }\end{array}$ \\
\hline 8 Union St, Southwark, London & & $*$ & & & & & & & & & & Three triple vases, red deer skull \\
\hline Scole-Dickleburgh, Norfolk & & $*$ & $*$ & $*$ & & 1 & & & 1 & & 1 & \\
\hline Stonea, Cambridgeshire & & $*$ & $*$ & $*$ & & & & & 1 & & & \\
\hline Bainesse (Site 46), Catterick, Yorkshire & & & $*$ & $*$ & & 1 & & 1 & 3 & 1 & 1 & \\
\hline Billingsgate Buildings, London & & $*$ & $*$ & * & 1 & 2 & 1 & & & & & \\
\hline $\begin{array}{l}\text { Pasture Lodge Farm, Long Bennington, } \\
\text { Lincolnshire }\end{array}$ & & & & * & & 2 & 1 & & 1 & & 1 & \\
\hline Tolpuddle Ball, Dorset & & $*$ & & & & & & & & & & \\
\hline Sheepen, Colchester, Essex & & $*$ & $*$ & $*$ & & 4 & 1 & & 1 & & & $2 \mathrm{x}$ ravens, a dog and a puppy \\
\hline Caerleon, Newport, Wales & & $*$ & $*$ & $*$ & & 2 & & & & 1 & 1 & \\
\hline Caister-on-sea, Norfolk & & & & $*$ & & 1 & 2 & & 2 & & & \\
\hline Segontium & & $*$ & $*$ & $*$ & 1 & 2 & & & 2 & & 2 & \\
\hline South Shields, Newcastle & & $*$ & $*$ & $*$ & & & & & & 1 & & \\
\hline Binchester, Co Durham & & $*$ & * & * & & 2 & & & 3 & 1 & & \\
\hline
\end{tabular}




\begin{tabular}{|c|c|c|c|c|c|c|c|c|c|c|c|c|}
\hline \multicolumn{13}{|l|}{ Table 2 (Continuated) } \\
\hline Bays Meadow Villa, Droitwich, Worcestershire & & * & & * & & 1 & & & 1 & & 1 & \\
\hline Redlands Farm, Stanwick, Northamptonshire & & * & $*$ & $*$ & & & & & 1 & & 1 & Radius from a small dog \\
\hline Springhead, Kent & & * & & $*$ & & & 2 & 1 & 1 & & 1 & Dog skeleton; pig and horse skulls \\
\hline Uley Shrines, Gloucestershire & & * & & * & & & & & & & & \\
\hline \multicolumn{13}{|l|}{ Saxon } \\
\hline Iona Monastery, Argyl & & * & $*$ & & 4 & & & & 1 & & & \\
\hline Iona, Argyl & & * & * & & 4 & & & & 1 & & & \\
\hline Lagore, Ratoath & & $*$ & $*$ & $*$ & 2 & 2 & 6 & 2 & 4 & & & \\
\hline Skaill, Deerness, Orkney & & & $*$ & * & 9 & 6 & 3 & 2 & 2 & & 2 & \\
\hline Barton Court Farm & & $*$ & $*$ & $*$ & & 1 & & 1 & & 1 & 1 & \\
\hline Crow hall park, Downham Market & & * & $*$ & & & & & & & & & \\
\hline Lake End Rd, Berkshire & & * & $*$ & * & & 1 & 1 & & 1 & 2 & & \\
\hline Lot's Hole, Berkshire & & & & & & & & 1 & & & & Red kite \\
\hline York Minster & & $*$ & $*$ & $*$ & & & & & 2 & 1 & 1 & \\
\hline York Minster & & $*$ & $*$ & $*$ & & 1 & & & & & & \\
\hline \multicolumn{13}{|l|}{ Medieval } \\
\hline Castle Park, Dunbar, East Lothian & & & & & 3 & 3 & & & & $*$ & & \\
\hline Brougham Castle, Cumbria & & * & $*$ & & & & & & 1 & & 1 & \\
\hline Iona, Argyl & & * & $*$ & & 1 & 2 & & & & & & \\
\hline Anchor Church & & * & $*$ & $*$ & & & 1 & & & 1 & & MNI 5 goose wings (coracoids) \\
\hline High St, Perth & & $*$ & $*$ & $*$ & & & & & 1 & & 1 & \\
\hline Hungate, York & $*$ & & & & & & & & & & & \\
\hline Coppergate, York & & * & $*$ & & 1 & & & & & & & \\
\hline Crown Car Park, Nantwich, Cheshire & & * & $*$ & * & & & & 3 & 3 & & & \\
\hline Perth High St, Perth & & $*$ & $*$ & $*$ & & 2 & 2 & 1 & 2 & & 3 & \\
\hline
\end{tabular}

TABLE 2

Other taxa associated with the finds of eagles. Fowl= Gallidae; goose=Anseridae; duck= Anatidae; seabirds= Laridae, Phalacrocoracidae, Alcidae, Procellariidae, Sulidae, Stercorariidae; raptors= Strigiformes, Accipitridae, Falconidae; waders= Scolopacidae, Ciconiidae, Charadriidae, Haematopodidae, Ardeidae, Gruidae; waterfowl= Gaviidae, Podicipedidae, Rallidae, Pelecanidae; small birds= Passerines, Turdidae; other $=$ Columbidae, Phasianidae. $\mathrm{MNI}=$ Minimum number of individuals.

into this period, and implies either the continued use of the tomb over a period of a thousand years or later re-use. The very landscape that eagles inhabit may be a clue to their symbolic potential. All the Neolithic/Bronze Age tombs containing white-tailed eagles are located on cliff tops or in coastal areas - landscapes favoured by these birds, and their remains may have been used to sustain the sense of place and associated memories (Jones, 1998: 314). Best and Mulville have suggested that considerable effort was required for the procurement of these eagles, which may have necessitated curation over a period of time (Best \& Mulville, Forthcoming).

As well as the presence of whole eagles, the deposition of a group of eagle talons ( $3^{\text {rd }}$ phalanges) within the tomb at Isbister implies their deliberate inclusion as possible totems or talismans. At both other Bronze Age sites it is again the talons that were targeted (Table 1). The golden eagle toe bones from a cemetery at Skilmafilly, Aberdeenshire were found with the cremation of a child. The bones themselves, although burnt, were not calcined to the extent of the child, making it likely that they were originally covered or placed in a pouch that gave them some protection from the fire (Smith, 2012). A perforated white-tailed eagle third phalanx was recovered from Potterne, Wiltshire that had likely been worn as a charm or ornament (Locker, 2000). Although it is a small sample, it is tempting to consider that eagle talons in this period may reflect an association between the birds and the transference of a particular quality. Although there is no specific evidence that eagles played a role in Bronze Age European culture, it was during this period that demonstrations of power and status increased in importance socially (Harding, 2000) and the use of eagle talons may have been specific to a particular stratum of society.

IRON AGE (800 BC-AD 43)

The number of eagle finds from Iron Age sites increases dramatically compared with those of 
previous periods, although they remain relatively common in the Orkney islands (Table 1 and Figure $3 \mathrm{D})$. They can be grouped into two categories. The first are those from coastal or island settlements (Cladh Hallan, South Uist; Howe and Skaill, Orkney; Meare and Glastonbury lake villages, Somerset; Ower, Purbeck) where exploitation of the local wetlands for food is evident in the number of waterfowl, seabirds and waders in their assemblages (Table 2). At these sites, the incorporation of eagles within midden or rubbish accumulations may have been as food; to reduce competition between people and the birds; or their acquisition during fowling trips for symbolic purposes. The presence of $3^{\text {rd }}$ phalanges at Cladh Hallan and Meare Lake Village implies that they may have importance as talismans, possibly continuing a Bronze Age tradition. This is exemplified by the find of four perforated eagle talons from an Iron Age grave at Abekas, Skivarps, Sweden (Clark, 1948: 130).

The second group come from more inland settlements in eastern England whose populations do not appear to utilise local resources to such an extent. It is at these sites that butchery or cut marks are evident on wing bones: a radius and ulna from Cheriton Road, Kent (Figure 5) and humeri from Fenny Lock, Milton Keynes and Puckeridge and Braughing, Hertfordshire, caused by disarticulation of the wings. The importance of feathers to Iron Age communities has been illustrated by finds of corvid wings at Danebury (Serjeantson \& Morris, 2011: 102) and early Irish literature describes the druid Mug Ruith who wore a feathered headdress and used a feather cloak during divination (Aldhouse Green, 2004: 146). These two groups of sites are not mutually exclusive, and it is possible that eagles recovered from coastal sites were also utilised for their feathers, but only inland populations specifically targeted the wings.

Two other sites produced eagle bones. The femur of a white-tailed eagle was recovered from a ditch at Longthorpe, Cambridgeshire alongside a crane tarsometatarsal with cut marks at the distal end. At Dragonby, Lincolnshire two white-tailed eagle skeletons were recovered from ditches along with finds of buzzard, goshawk and red kite. Given the proximity of the site to the Humber estuary, it is possible that this find fits with the first category of eagle deposits - the presence of other raptors indicating the persecution of other birds that would have competed for resources. Alternatively, it may

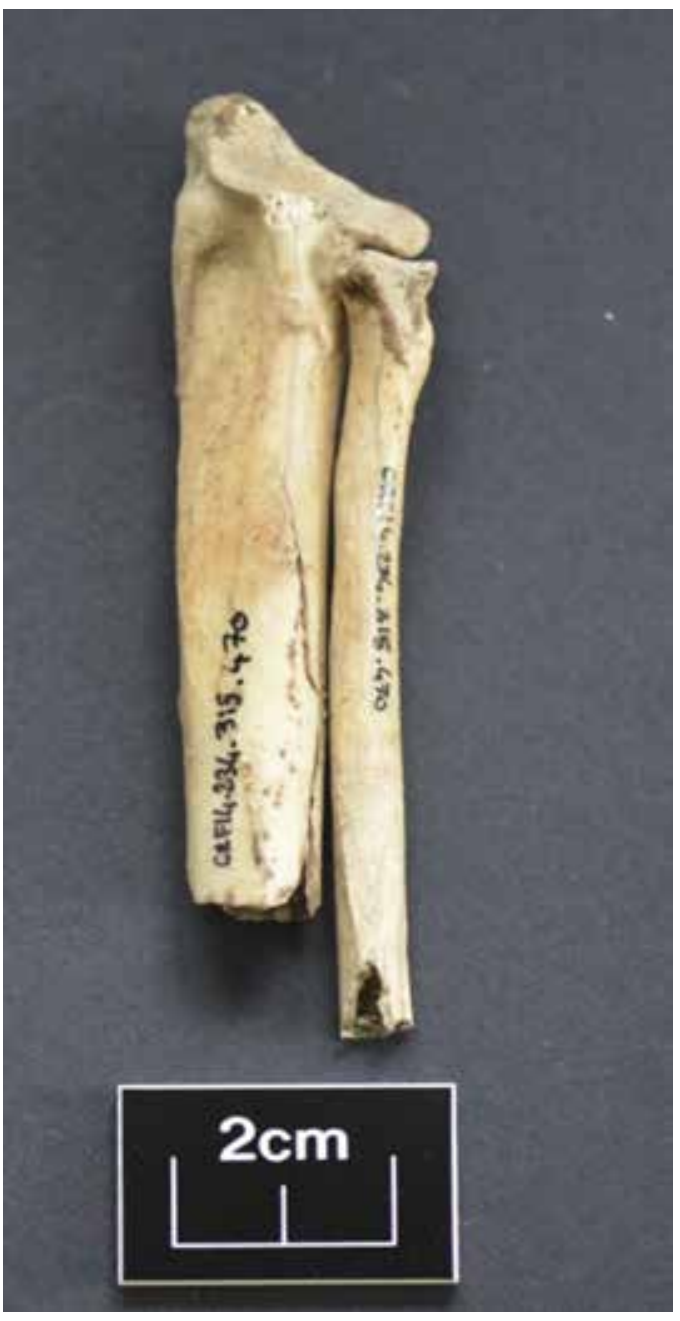

FIGURE 5

White-tailed eagle wing bones from cheriton sports field that had been carefully butchered. Photo by author.

represent the deliberate collection of large and impressive birds for their feathers.

Although problems of preservation will contribute to the preferential recovery of eagle remains in certain parts of the country, it is notable that wing bones are recovered in the east. They may represent new ideas being transmitted from contact with the Roman world through trade routes, as they show considerable similarities with subsequent trends observed in Roman Britain. Similarly, the recovery of phalanges from Orkney and south west England reflect the areas from which talons were recorded in the preceding period, possibly as a continuation of pre-existing traditions in these areas. 
ROMAN (AD 43-410)

Increasing numbers of eagle finds continue into the Roman period, particularly at inland sites (Table 1 and Figure 3E). The absence of finds from Scotland, Wales and Ireland in this period is largely due to the continuation of the Iron Age in these countries until the early Christian period, broadly contemporary with the Saxon period in England. The association between eagles and heavily exploited wetland or coastal environments appears to decline in this period, although a diversity of taxa can be observed at many settlement and military sites (Table 2). At four of the five urban sites (Dunstable, Leicester, London and Winchester) eagle remains were recovered in association with the deliberate deposition of other animals and artefacts (Table 2) implying their inclusion in a ritual or symbolic context. This also occurs at the sanctuary complex at Springhead, Kent, while the eagle bone from Uley was deposited in the late $1^{\text {st }}$ century AD before the large Roman temple complex was built, in relation to votive deposits at a pre-existing late Iron Age shrine (Woodward \& Leach, 1993).

Eagles were highly symbolic in the Roman world. Pliny in his Natural History (Bostock \&
Riley, 1855) describes how, "Of all the birds with which we are acquainted, the eagle is looked upon as the most noble, and the most remarkable for its strength" (Book 10, chapter 3). This, combined with the belief that they could not be hit by lightning, and indeed were the carriers of thunderbolts (Book 2, chapter 56), made them the armour-bearers of Jupiter (Book 10). In her comprehensive study of eagle imagery in Roman Britain, Durham (2013) observes that they were symbolically significant, conveying status, representing the Emperor and imperial Rome. They were considered honourable, strong and portents of success; they embodied the glory of death, and their association with Jupiter led them to become the legionary emblem of the Roman army from the $2^{\text {nd }}$ century (ibid). The association between eagles and the army may therefore explain their abundance on Roman military sites (Figure 6). Mass-collection events are evident at several such sites: The fort at South Shields, Newcastle contained the remains of 14 white-tailed eagles - 13 from the commandant's house and one from the barracks. At the late Roman-early Saxon fort at Binchester, County Durham a single collection and butchery event is evident in the remains of at least three white-tailed eagles and two golden eagles. Over

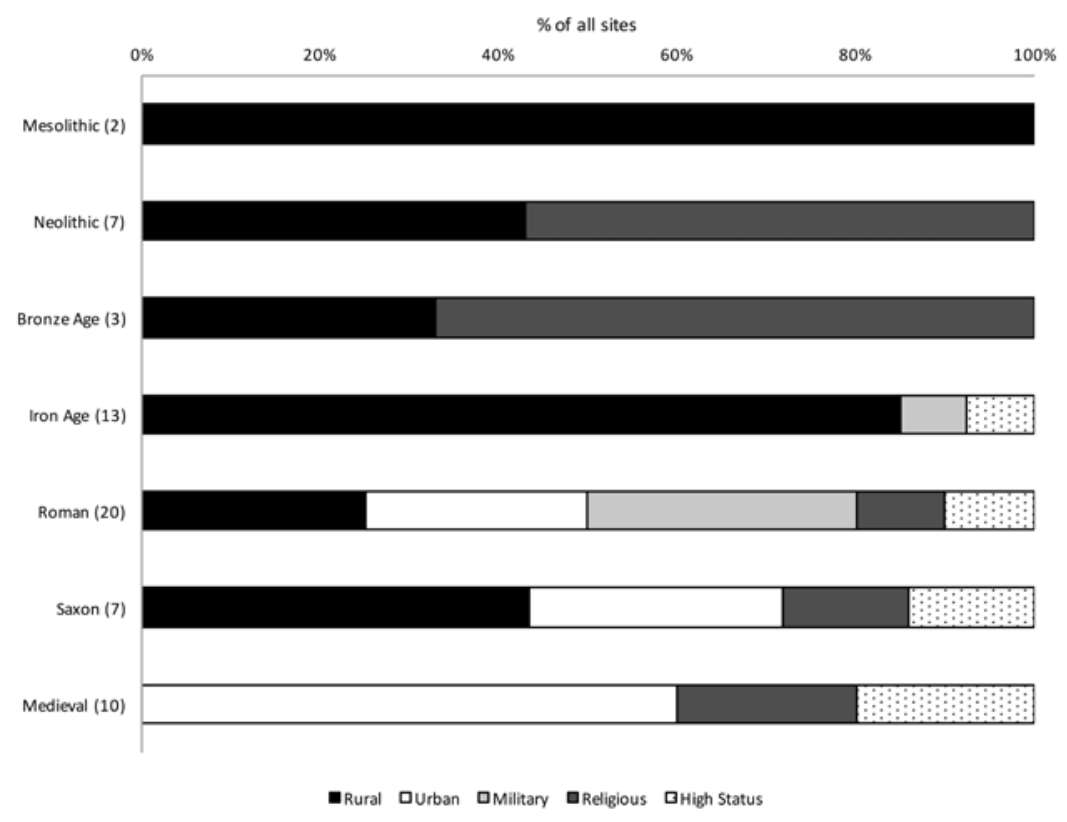

FIGURE 6

Proportion of assemblages recorded from various site types by period. Rural= settlement, midden, camp, pit cluster; urban= trading site, town; religious = tomb, cemetery, henge, monastery/ abbey; military= fort; High status= castle, villa, crannog, oppida. 
half the bones were from the wings, with no foot bones recovered, and the proximal humeri exhibited cut and chop marks. Additionally, the remains of at least two birds from single contexts are recorded from military sites at Sheepen, Colchester, Segontium, Gwynedd and possibly York Minster (see description in the Saxon section).

Not all incidences of eagles in the archaeological record will be anthropogenic, and the presence of white-tailed eagles in a commensal role, as scavengers in urban environments across Europe has been described by Mulkeen \& O'Connor (1997: 443). It is therefore possible that at least some white-tailed eagle finds at nucleated settlements represent natural deaths of birds taking advantage of an ecological niche that benefitted their propensity to scavenge. As well as urban sites, this can also be applied to some Roman fort and rural settlements and the small town at Scole-Dickleburgh, where refuse was likely to have been available. However, the association of some eagle remains with the military and ritual deposits in urban environments implies that they often had origins beyond the commensal.

\section{SAXON (AD410-1066)}

The number of eagle remains from the Saxon period decline sharply from the previous phase, coming from island or coastal sites in Scotland or Ireland and the south and east of England (Table 1 and Figure 3F). It is possible, given their low numbers that they underwent extirpation following the collection events observed in the previous period. Alternatively, this perceived geographical scarcity could be a product of small sample size. In areas with little Roman influence eagles continue to be associated with the exploitation of other wild birds at island sites, particularly Iona, Lagore and Skaill (Table 2). As in the Neolithic, this is a time when wild resources are not generally utilised in England (Holmes, 2011: 23; Sykes, 2014: 69) and this is reflected in the data, where few wild bird remains were recorded at inland sites. There is relatively little detailed information on the eagle remains from this period, although the recovery of two fragments of bone from a sunken featured building (SFB) at Barton Court Farm may have resulted from a deliberate deposition. The closure of SFBs often involved backfilling with rubbish alongside symbolically significant remains such as complete pottery vessels, animals such as dogs and cats, and cattle skulls (Morris \& Jervis, 2011). The trading site at Lot's Hole and Lake End Road produced two white-tailed eagle bones, one of which was a third phalanx that may have been used as a totem or amulet, and the other a butchered tibiotarsus, which indicates processing, possibly in preparation of just such an amulet. The use of totems in pre-Christian Saxon contexts is well-documented, and finds of perforated teeth from boar, beaver, dog and wolf occur in burial deposits and more domestic contexts (Hicks, 1993: 24). Raptors are often portrayed in Saxon iconography, some of which may be eagles; in many cases representing, "celestially-derived qualities and earthly power" (Dickinson, 2005: 158).

The white-tailed eagle remains from York Minster, at the site of a former Roman Basilica and barracks are likely to be from earlier contexts. There is a high degree of residuality at this site (Rackham, 1995), which makes it possible that these eagle remains were associated with the Roman military occupation of the site. While this fits with trends described for that period their provenance as Saxon remains cannot be dismissed.

\section{MEDIEVAL (AD 1066-1540)}

The medieval period is represented by eagle finds from a wide geographic spread, although they are absent from the south (Table 1 and Figure 3G). The association of eagles with medieval castles at Dunbar and Brougham could be related to falconry. Eagles are referred to in the $15^{\text {th }}$ century Boke of St Albans as suitable for an Emperor, and although they were used for hunting in areas of central Asia, a tradition that continues today in Kazhakhstan (Soma, 2012), it is unlikely that they were used in this way in Europe (Cummins, 1988: 188). Instead it likely reflects the perception from contemporary bestiaries (medieval treatise describing the physical and perceived moral attributes of animals) that eagles were king of the birds and therefore worthy of the elite, an association also reflected in their use as heraldic symbols (Cannan, 2003: 200). There would almost certainly be some novelty value associated with keeping an eagle in an aviary (Oggins, 2004: 115), which makes it a likely explanation for these birds at such a high-status sites. 
Eagle finds exhibit a propensity towards medieval urban sites (Figure 6), and their role as commensal scavengers is an explanation for their occurrence on such sites (Mulkeen \& O'Connor, 1997). However, it is also pertinent that many other birds of prey are recovered from medieval urban sites, not as scavengers but through trade of falconry birds (Mulkeen \& O'Connor, 1997; Holmes, forthcoming). This explanation is most likely at Crown Car Park, Nantwich, where the eagle remains were found alongside goshawk and sparrowhawk, and Perth High St, as they were associated with buzzard and peafowl. Although white-tailed eagles are naturally inclined to scavenge from settlements, it is less likely to be the case with golden eagles (Mulkeen \& O'Connor, 1997: 442), and the trade in birds presents an alternative route for the golden eagle bone recorded at Hungate, York. The institutionalised persecution of eagles as predators on livestock is recorded in England and elsewhere in Europe, and the presentation of the heads, wings and legs of these birds in return for payment is evidenced in $15^{\text {th }}$ century texts from Portugal (Moreno-García \& Pimenta, 2010: 266), and $16^{\text {th }}$ century ordinances from England (Dannenfeldt, 1982: 554). This must therefore remain a possible reason for their presence on some sites.

\section{PEOPLE AND EAGLES}

The evidence so far has largely been restricted to the physical (quantifying eagle remains), economic (what they may have been used for) and status (who may have had access to them or their remains). This section aims to move beyond these functional ideas of eagles as passive perceptions, to incorporate ideas of the relationships that may have underpinned human and eagle interactions in the past. The presence of low numbers of golden and white-tailed eagles in all periods implies that they were a scarce, yet extant part of the landscape. However, the brief descriptions of findings presented above have revealed changing contextual associations that imply perceptions of eagles were not stable. While today in Britain eagles are considered predators by farmers, and birds of wonder by many of the tourists who flock to observe them, it is naïve to presume similar, superficial dichotomies in the past. There are few ways to understand what eagles could have meant on a quotidian, spiritual or sym- bolic level to past societies, but some ideas can be taken from ethnographic accounts and documentary sources.

There are two recurring and cross-cultural themes tied to eagle lore that may help when considering how eagles were perceived in the past. The first is their representation of long-lived strength, courage and wisdom, and the second is their association with gods and natural forces. The eagle's metaphorical relationship with the sun, lightning and thunder are described in historical sources. The writings of Pliny (White, 1960; Durham, 2013) were likely the source of the descriptions in medieval bestiaries and similar beliefs can be observed ethnographically in some Native American traditions (Lawrence, 1993), Chinese painting and Tibetan Buddhist scripts (Austine Waddell, 1972: 447; Eberhard, 1986: 105). Their association with gods is also widespread, and eagles accompany the Greek god Zeus, Roman Jupiter and Germanic Odin/ Woden, while the Celtic god Lleu and Norse Odin could both transform into an eagle (Matthews \& Matthews, 1995), and the Garuda, half human, half eagle is a deity and mount of Hindu and Buddhist gods (Beer, 2003). Eagles also play a role in the Christian faith, acting as a messenger in the $B i$ ble between earth and heaven (Exodus 19:4), and some American south plains tribes believe they represent the Father who oversees the earth, acting as a means of communication between people and supernatural forces (Lawrence, 1993).

Despite these consistently well documented beliefs relating to eagle lore, they are rarely considered in relation to zooarchaeological remains, although the socially and culturally symbolic nature of eagles in Scottish island tombs and funerary environments has been considered in depth by Best and Mulville (Forthcoming). Most interpretations tend to be standard, incorporating comments on the local environment, possible uses as amulets, the importance of feathers and their presence as scavengers. The challenge now is to go beyond these interpretations, to consider what eagles could have meant to the people sharing a landscape with them, and how eagles responded to changes in human settlement.

\section{BEYOND ENVIRONMENT}

As noted previously both species of eagles were more common in the past, and archaeologically 
the white-tailed eagle is more often recorded due largely to its propensity to share lowland habitats with people. Both eagle species are monogamous and will return to nesting sites over several breeding seasons, if not all their lives, which gives them a permanence in the landscape. While both taxa would have been more common throughout Britain in the past, the golden eagle has a territory of c.200 $\mathrm{km}^{2}$, while white-tailed eagles live within a much smaller area c. $30-70 \mathrm{~km}^{2}$, making it likely that the latter would have been a more common sight (Baxter, 1993b: 79). The spectacular courtship performance of white-tailed eagles involves them joining talons in the air and cartwheeling towards the land, and this, when combined with their more vociferous habits and smaller territories, would have made them obvious agents within the landscape, leading people to become accustomed to and familiar with individual birds.

Despite this, there is no evidence for prehistoric (Neolithic to Iron Age) or Saxon populations to have actively sought to capture eagles, either for raw materials or as hunted animals in the way that they were in the late $19^{\text {th }}$ century. This suggests that, although they were visible in the landscape, eagles were commonly perceived as 'other', as having no role in the functional, quotidian life course of most people. If eagles were perceived as belonging to the sphere of the supernatural, or being bestowed with particular strengths this may have made them taboo (Serjeantson, 2009: 336). The potential limitations of Bronze Age evidence to amulets and burial companions implies that only in certain circumstances could eagles be used.

The association of eagles with coastal communities of the Neolithic, Iron Age and Saxon periods who included fowling amongst their resource gathering suggests a different relationship existed. Maybe to a population who devoted much of their time to hunting birds, eagles would have seemed less 'other', and more familiar. The capture of eagles in these circumstances may have been specifically targeted when the need arose or taken opportunistically. The differences between people living in these coastal locations and those in more inland sites are notable, not just for the presence of eagle remains, but the importance of hunting to these marginal communities at a time when the rest of the population actively resisted engaging with the wild. It is likely that this would have set them apart, and these groups could have been treated as socially and culturally different.

\section{BEYOND SCAVENGERS}

Deliberate capture of eagles in the Roman and medieval periods implies a changing relationship between people and the wild, where eagles were actively sought out, either as resources, for rituals, or as status symbols. It may be no accident that it is during these periods that increasing settlement density brought new opportunities for white-tailed eagles, whose appearance at urban and nucleated settlements reflects their role as a commensal species. By actively seeking out food in such a way, eagles themselves were engaging with human settlements. Their presence would have been obvious, and the agency of eagles to visit a settlement must have had considerable impact on those living there. Whether with a sense of pleasure, awe, fear, or annoyance, the movement of eagles into the domestic sphere would have been a new facet of life uncommon in the dispersed, smaller settlements of preceding periods.

It is implicit in many reports that eagle remains in domestic settings were killed for their scavenging habits, or because they were pests to farmers, but it is also possible that they were caught for food. It is unlikely that eagles would have been a staple in any period, as it would be less productive to target eagles than birds that flock in large numbers (Best \& Mulville, forthcoming). Their presence amongst domestic refuse, often alongside the remains of birds and animals that would have been eaten, does not rule out the possibility that eagles could have been opportunistically caught for food in the past, particularly at some coastal settlements where the consumption of wild birds was an integral part of the diet. However, the data do not suggest that this was widespread, illustrated by the presence of eagles at Roman urban sites. Some may have been killed as scavengers or for meat, but the high proportion recorded from contexts as part of a ritual deposition indicates that there was more to their presence than scavenging pests, and they likely inhabited several roles.

Another role as scavenger lies in the arena of combat, and in both Saxon and Scandinavian mythology the eagle is associated with the dead on the battlefield (Baxter, 1993b: 79). In contrast to the more domestic human-eagle relationships occurring within the commensal sphere, this habit may have led to associations between eagles and transformations of people after death, which is a 
widespread phenomenon documented by Roman, Scandinavian and Saxon sources, with artefactual evidence indicating that it was also prevalent in the Iron Age (Baxter, 1993b; Hicks, 1993; Aldhouse Green, 2004: 161; Durham, 2013). Indeed, it is such transformations that may underlie the association of eagles with the dead in Orcadian tombs.

The role of people as scavengers should also be considered. It is likely that some eagle remains originally came from finds of dead birds. The collection of wings and phalanges from birds that had died naturally would provide an easy opportunity to procure valued materials.

\section{BEYOND FEATHERS}

The suggestion that eagle wings were used for brushes or feathers for arrow flights was put forward by Parker (1988) in his seminal paper on the Birds of Roman Britain, which is more often quoted than any other when explaining the presence of eagles on British sites of all periods. These interpretations remain valid, and it is known that feathers were used as fletching from the Mesolithic period (Clark, 1948). The potential value of eagle body parts go far beyond these functional possibilities, including their use as medicine and the bestowing of transformative power on an object and/ or the owner or wearer of that object.

Pliny, in his Natural Histories Books 29 and 30 describes some of the curative properties of eagles. Their brains and gall were used to treat eye disease; the feet for joint pains; and the brains for jaundice (Bostock \& Riley, 1855), while the bile of eagles is documented as being used in medieval eastern Mediterranean medicine (Lev, 2008). The Anglo Saxon Lacnunga compiled in the $10^{\text {th }}$ or $11^{\text {th }}$ century specifies the use of marrow from an eagle in a salve to help with broken bones (Storms, 1948: 42). Today eagles are one of the most common birds used for medicine in Africa (Derwent \& Mander, 2017), while in Afghanistan eagles are believed to have power to cure stomach and heart problems (Ostrowski, 2006). It is therefore probable that eagles in the past were considered important for their perceived medicinal properties, although this is difficult to observe in the archaeological record. As recently as the early $19^{\text {th }}$ century eagle claws were recorded as a cure used for jaundice in the Faroe Islands (Clark, 1948: 129).

Eagle feathers are also considered to have, "supernatural and curative functions" (Lawrence, 1993: 21) by many Native Americans. The wing feathers can be used in the form of a brush or fan to heal, and the downy chest feathers represent breath and life in certain ceremonies. The wearing of eagle feathers may bestow certain values, maybe even allowing the wearer to take on attributes of the eagle. It is possible that they could "break down distinctions between humans and animals" in such a way as the wearing of red deer antlers may have done at Mesolithic Starr Carr (Conneller, 2004), and the shamans of South American tribes believe that by wearing feathers they could become birds and convey messages to the gods in the sky (Serjeantson, 2009: 339). The prevalence of wing bones with cut marks from Iron Age and Roman sites implies that feathers were indeed sought after. The carefully cut ulna and radius from Cheriton Rd, Kent (Figure 5) would have held the long wing feathers and may indeed be the remains of a fan or brush for ceremonial use - if so, it provides a small insight into a ritual process. Early evidence for the collection of eagle feathers comes from pre-Neolithic Jordan where the wing bones (radii and ulnae) of a large group of eagles had been removed, and the authors speculate that these may have been traded as decorative or ritual fans or brushes (Martin et al., 2013). The widespread collection of eagle feathers for ornamentation or adornment has been identified at Neanderthal sites across Europe, which adds to the growing body of work suggesting that Neanderthals had cognitive functions comparable to modern humans (Finlayson et al., 2012).

The mass-collection events from Roman forts at Binchester, Sheepen, South Shields and Segontium are indicative of the deliberate capture and killing of white-tailed and golden eagles. Except for the Orcadian tomb assemblages, and the group of eagles and other raptors at the Iron Age site of Dragonby, Lincolnshire, this appears to be a very specific, repeated and deliberate activity relating to the roman military. The prevalence of wing bones could indicate the primary objective was collection for feathers. Links between the Roman military and eagles may have caused a bond to have formed in the psyche of soldiers with these birds. Maybe the 'collection' of eagles occurred at a special time in the calendar, as a rite of passage, or in advance 
of or following a major battle that went beyond the simple procurement of feathers.

In some parts of Siberia golden eagles were considered a totem animal and spirit helper, and parts of the bird would be attached to the robe of a Shaman (Mannermaa, 2008: 72). The use of talons from raptors may have had associations with power and hunting skill (Serjeantson, 2009: 225), and in Afghanistan eagle talons are used as amulets to protect the home (Ostrowski, 2006). The apparent importance of eagle feet in the Bronze Age and at some Iron Age, Roman and Saxon sites may therefore relate to a perceived symbolic manifestation of a physical property associated with eagles such as strength or protection. A charm specified in the British Museum Royal Manuscript No.4 dated to the twelfth century describes the removal of a wen (cist or lump) involving the following instruction, "Under the wolfs paw, under the eagle's feather, under the eagle's claw, ever may you wither", which has been interpreted as instructions for the preparation of an amulet (Storms, 1948: 155). Again, the earliest deliberate collection and use of eagle phalanges comes from a number of Neanderthal sites, where the nature of butchery marks and wear patterns have been used to imply their use as jewellery (Radovčić et al., 2015) or for "symbolic expression" (Romandini et al., 2014: 8), which emphasises the effect that eagles had on the psyche of hominins within a deep-time perspective.

\section{CONCLUSION}

This short review of the evidence for eagles in Britain's past has served to highlight some of the possibilities to move thinking beyond the standard environment/ scavenger/ feather/ symbolism description. One criticism that could justifiably be made is that the ethnographic and historical case studies are too wide-ranging and disparate. This is rather the point - the strong cross-cultural and longterm symbolism of eagles and images of protection, strength, wisdom and associations with deities suggest they are likely to have had similarly strong influences on the people sharing a landscape with them further back in time. The scarcity of eagle finds from Britain suggests that, while they would have been present in many parts of the country as familiar sights, they were not considered part of the everyday sphere. Exceptions to this exist, those who were used to the hunting and trapping of birds perhaps targeted eagles for materials or rituals or took them as incidental finds when out hunting a practice that may have set them apart from contemporary inland populations where the capture of eagles may have been taboo. Often their remains seem to have resulted from specific uses, and there is evidence that talons and wings were targeted perhaps being bestowed with a power or attribute that could be transferred to the owner, and indeed may only have been accessible to a certain class of person. The transmission of ideas from the Roman world through international trade routes is evident, possibly leading to a critical reduction in the numbers of eagles in eastern England prior to the later post medieval culls. The association of eagles with the Roman army is also notable and mass collection of these birds at several forts perhaps represents a special event or rite of passage. Although several new ideas concerning the possible role of eagles in Britain's past have been postulated, the importance of interpreting zooarchaeological finds alongside their contextual and cultural situations is key.

\section{REFERENCES}

Albarella, U. \& Pirnie, T. 2008: A Review of Animal Bone Evidence from Central England Evidence [data-set]. (doi:10.5284/1000317). Archaeology Data Service, York.

Aldhouse Green, M. 2004: An Archaeology of Images: Iconology and Cosmology in Iron Age and Roman Europe. Routledge, London.

Allen, M.; Blick, N.; Brindle, T.; Evans, T.; Fulford, M.; Holbrook, N.; Richards, J.D. \& Smith, A. 2015: The Rural Settlement of Roman Britain: an online resource [data-set]. (doi:10.5284/1030449). Archaeology Data Service, York.

Allison, E. 1997: Bird bones. In: Buteux, S.; Allison, E. \& Bellam, J. (eds.): Settlements at Skaill, Deerness, Orkney: Excavations by Peter Gelling of the Prehistoric, Pictish, Viking and Later Periods, 1963-1981: 247-248. B.A.R. (British Series) 260. Oxford.

Andrews, C. 1917: Report on the remains of birds. In: Bulleid, A. \& Gray, H.S.G. (eds.): The Glastonbury Lake Village: A Full Description of the Excavations and the Relics Discovered 1892-1907: 631-637. Glastonbury Antiquarian Society 2. Glastonbury.

Armour-Chelu, M. 1988: Taphonomic and cultural information from an assemblage of Neolithic bird bones 
from Orkney. In: Murphy, P. \& French, C. (eds.): The Exploitation of Wetlands: 69-76. B.A.R. (British Series) 186. Oxford.

Ashdown, R. 1979: The avian bones from Station Rd, Puckeridge. 92-7. In: Partridge, C. (ed.): Excavations at Puckeridge and Braughing 1975-9: 28-132. Hertfordshire Archaeology 7.

Austine Waddell, L. 1972: Tibetan Buddhism: With Its Mystic Cults, Symbolism and Mythology, and in Its Relation to Indian Buddhism. Dover, New York.

BAKER, P. 1998: The vertebrate remains from Scole-Dickleburgh, excavated in 1993 (Norfolk and Suffolk) A140 and A143 road improvement project. 29/1998. Ancient Monuments Laboratory report, London.

Baker, P. \& Worley, F. 2014: Animal Bones and Archaeology: Guidelines for Best Practice. English Heritage, Portsmouth.

BAXter, I. 1993a: An eagle, Haliaeetus albicilla (L.), skull from Roman Leicester, England, with some specultations concerning the palaeoecology of the Soar valley. Circaea 10(1): 31-37.

BaXter, I.L. 1993b: Eagles in Anglo-Saxon poems. Circaea 10(2): 78-81.

BeER, R. 2003: The Handbook of Tibetan Buddhist Symbols. Serindia, London.

Best, J. \& Mulville, J. 2013: Between the sea and sky: the archaeology of avian resource exploitation in Scottish island environments. In: Daire, M.Y.; Dupont, D.; Baudry, A.; Billard, C.; Large, J.M.; Lespez, L.; Normand, E. \& Scarre, C. (eds.): Ancient Maritime Communities and the Relationship Between People and Environment Along the European Atlantic Coasts: 417-426. B.A.R. (International Series) 2570. Oxford.

- Forthcoming: Birds in Death: Avian Archaeology and the Mortuary Record in the Scottish Islands. in A. Livarda and R. Madgwick (eds.) Bioarchaeology of Ritual and Religion. Oxford, Oxbow

Bostock, J. \& Riley, H. 1855: The Natural History. Pliny the Elder. Taylor and Francis, London.

BRAmwell, D. 1981: Report on the bones of birds. In: Reece, R. (ed.): Excavations in Iona 1964 to 1974: 45-46. Institute of Archaeology (Occasional Publication) 5. London.

- 1983: The bird remains. In: Hedges, J. (ed.): Isbister, a Chambered Tomb in Orkney:159-170. B.A.R. (British Series) 115. Oxford.

- 1994: The bird remains. In: Ballin-Smith, B. (ed.): Howe: Four Millennia of Orkney Prehistory Excavations 1978-1982: 153-157. Society of Antiquaries of Scotland, Edinburgh.
- 2006: Birds. In: Hurst, D. (ed.): Roman Droitwich: Dodderhill Fort, Bays Meadow Villa, and Roadside Settlement: 220-221.CBA Research Report 146. York.

Cannan, F. 2003: The myths of medieval heraldry. Nottingham medieval studies 47: 198-216.

Clark, G. 1948: Fowling in prehistoric Europe. Antiquity 22(87): 116-130.

ConNeller, C. 2004: Becoming deer. Corporeal transformations at Star Carr. Archaeological Dialogues 11(1): 37-56.

Cowles, G. 1980: Bird bones. In: Jones, D. (ed.): Excavations at Billingsgate Buildings, Lower Thames Street, London, 1974. LAMAS Special Paper 4: 163.

Coy, J. 1987: The animal bone. In: Woodward, P. (ed.): The excavation of a late Iron age settlement and Romano-British industrial site at Ower: 114-119. Dorset Natural History and Archaeological Society 6. Dorset.

Coy, J. \& Hamilton-Dyer, S. 1993: The bird and fish bone. In: McCormick, F. (ed.): Excavations at Iona, 1988: 100-101. Ulster Journal of Archaeology 56: 78-108.

Cummins, J. 1988: The Hound and the Hawk. Phoenix Press, London.

CuRL, J. 2008: Faunal remains. In: Percival, J. \& Trimble, G. (eds.): Excavations at Crow Hall Park, London Road, Downham Market, 1999 - 2000: 323-326. Norfolk Archaeology XLV.

Cussons, J. \& Bond, J. 2010: The animal bone. In: Ferris, I. (ed.): The Beautiful Rooms are Empty: Excavations at Binchester Roman Fort, County Durham 1976-1981 and 1986-1991: 489-523. Durham County Council, Durham.

DANNENFELDT, K. 1982: The control of vertebrate pests in Renaissance agriculture. Agricultural History 56(3): 542-559.

Davidson, J.L. \& Henshall, A.S. 1989: The Chambered Cairns of Orkney: An Inventory of the Structures and their Contents. Edinburgh University Press, Edinburgh.

Davis, S. 1997: Animal Bones from the Roman site Redlands Farm, Stanwick, Northamptonshire, 1990 excavations. 106/97. Ancient Monument Laboratory Report Series, London.

Derwent, S. \& Mander, M. 2017: Kruger Park Birding: Birds and Muthi (Mediane). http://birding.krugerpark. co.za/birding-in-kruger-birds-and-muthi.html

Dickinson, T. 2005: Symbols of protection: The significance of animal-ornamented shields in early Anglo-Saxon England. Medieval Archaeology 49(1): 109-163. 
Durham, E. 2013: Symbols of power: the Silchester bronze eagle and eagles in Roman Britain. Archaeological Journal 170(1): 78-105.

EBERHARD, W. 1986: Dictionary of Chinese Symbols: Hidden Symbols in Chinese Life and Thought. Routledge, London.

English Heritage 1999: National Monuments Record Thesauri. http://thesaurus.english-heritage.org.uk/ accessed February 2012.

Evans, R.; O’Toole, L. \& Whitfield, D.P. 2012: The history of eagles in Britain and Ireland: an ecological review of placename and documentary evidence from the last 1500 years. Bird Study 59(3): 335-349.

Finlayson, C.; Brown, K.; Blasco, R.; Rosell, J.; Negro, J.; Bortolotti, G.; Finlayson, G.; Marco, A.; Pacheco, F. \& VidAL, J. 2012: Birds of a feather: Neanderthal exploitation of raptors and corvids. PloS one 7(9): 1-9.

FISHER, C. 1986: Bird bones from the excavation at Crown Car Park, Nantwich, Cheshire. Circaea 4(1): 55-65.

Ford, S.; Taylor, K.; Cannon, P.; Gleave, M.; HamilTON-Dyer, S.; MCKInLey, J.; Richards, D.; SMith, A.; Timby, J. \& Williams, D. 2001: Iron age and Roman settlements, with prehistoric and Saxon features, at Fenny Lock, Milton Keynes, Buckinghamshire. Records of Buckinghamshire 21: 79-124.

GelLing, M. 1987: Anglo-Saxon eagles. Leeds Studies in English 18: 173-181.

Gidney, L. 1992: The animal bone. In: Williams, J. (ed.): Excavations at Brougham Castle, 1987: 120-121. Transaction of the Cumberland and Westmorland Antiquarian and Archaeological Society 92.

Gray, H. \& Cotton, M. 1966: The Meare Lake Village Volume 3. Taunton Castle, Taunton.

Grimm, J. 2011: Springhead Sanctuary site. In: Barnett, C.; McKinley, J.; Stafford, E.; Grimm, J. \& Stevens, C. (eds.): Settling the Ebbsfleet Valley. High Speed 1 Excavations at Springhead and Northfleet, Kent. The Late Iron Age, Roman, Saxon and Medieval Landscape Volume 3: Late Iron Age to Roman Human Remains and Environmental Reports: 15-31. Oxford Wessex Archaeology, Oxford.

Hambleton, E. 2008: Review of middle Bronze Age late Iron Age faunal assemblages from Southern Britain. English Heritage Research Department Report Series 71-2008.

Hamilton-Dyer, S. 1999: Animal bones. In: Hearne, C. \& Birbeck, V. (eds.): A35 Tolpuddle to Puddletown Bypass DBFO, Dorset, 1996-8: Incorporating Excavations at Tolpuddle Ball 1993. Wessex Archaeology, Salisbury.
Hardey, J. 2006: Raptors: A Field Guide to Survey and Monitoring. The Stationery Office, Edinburgh.

Harding, A.F. 2000: European Societies in the Bronze Age. Cambridge University Press, Cambridge.

Harman, M. 1993: The animal bones. In: Darling, M. \& Gurney, D. (eds.): Caister-on-Sea. Excavations by Charles Green 1951-5: 223-228. East Anglian Archaeology 60. Ipswich.

- 1994: Bird bones. In: Leary, R. (ed.): Excavations at the Romano-British Settlement at Pasture Lodge Farm, Long Bennington, Lincolnshire, 1975-77 by HM Wheeler. Trent \& Peak Archaeology Trust 52. Lincoln.

- 1996: Bird bones. In: May, J. (ed.): Dragonby. Report on excavations at an Iron Age and Romano-British settlement in Lincolnshire: 162-163. Oxbow Monograph 61. Oxford.

- 1997: Bird bone. In: Barber, J. (ed.): The excavation of a stalled cairn at the Point of Cott, Westray, Orkney: 149-151. Scottish Trust for Archaeological Research, Edinburgh.

Hart-Davis, D. 2002: Fauna Britannica. Weidenfeld and Nicolson, London.

Hatting, T. 1968: Animal bones from the basal middens. In: Liversage, G. (ed.): Excavations at Dalkey Island, Co. Dublin, 1956-1959: 172-174. Royal Irish Academy Section C 66.

Hicks, C. 1993: Animals in Early Medieval Art. Edinburgh University Press, Edinburgh.

Holmes, M. 2004: Crowland, Anchor Church (CAC04): animal bone assessment. Unpublished Archaeological Project Services Report.

- 2011: Food, Status and Complexity in Saxon and Scandinavian England: An Archaeozoological Approach. Unpublished $\mathrm{PhD}$ thesis, University of Leicester.

- 2014: Animals in Saxon and Scandinavian England: Backbones of Economy and Society. Sidestone, Leiden.

- 2016: Animal bones. In: McNicoll-Norbury, J. (ed.): Iron Age and Early Roman occupation and a Middle Iron Age burial at Cheriton Road Sports Ground, Cheriton Road, Folkestone, Kent. Thames Valley Archaeological Services Unpublished Report CRF14/234.

- forthcoming: Southern England: A Review of Animal Remains from Saxon, Medieval and Post Medieval Archaeological Sites. English Heritage Research Report. London.

JoNES, A. 1998: Where eagles dare: landscape, animals and the Neolithic of Orkney. Journal of Material Culture 3: 301-324. 
Jones, E. \& Horne, B. 1981: Analysis of skeletal material. In: Matthews, C. (ed.): A Romano-British cemetary at Dunstable: 69-72. Bedfordshire Archaeological Journal 15: 1-72.

KING, J. 1987: The animal bones. In: Dawn, P. (ed.): Longthorpe II the Military Works-Depot: An Episode in Landscape History: 185-193. Britannia Monograph Series 8.

LAWRENCE, E.A. 1993: The symbolic role of animals in the Plains Indian sun dance. Society and Animals 1(1): 17-37.

Lev, E. 2008: Practical Materia Medica of the Medieval Eastern Mediterranean According to the Cairo Genizah. Brill, Leiden.

LeVITAN, B. 1993: Vertebrate remains. In: Woodward, A.D. \& Leach, P.J. (eds.): The Uley Shrines: 257-345. English Heritage/British Museum Press, London.

Levitan, B. \& Serjeantson, D. 1999: The animal bone. In: Halpin, C. \& Barclay, A. (eds.): Excavations at Barrow Hills, Radley, Oxfordshire Vol 1: The Neolithic and Bronze Age monument complex. Oxford Archaeological Unit, Oxford.

Locker, A. 2000: Animal Bone. In: Lawson, A. (ed.): Potterne 1982-5: Animal Husbandry in Later Prehistoric Wiltshire: 101-119. Wessex Archaeological Report 17. Salisbury.

Luff, R. 1985: The fauna. In: Niblett, R. (ed.): Sheepen, and Early Roman Industrial Site at Camulodaunum: 143-153. CBA Research Report 57. York.

Maltby, J.M. 1990: The exploitation of animals in the Stonehenge environs in the Neolithic and Bronze Age. In: Richards, J. (ed.): The Stonehenge Environs Project: 57-61. Historic Buildings and Monuments Commission for England Archaeological Report 16.

- 2010: Feeding a Roman Town: Environmental Evidence from Excavations in Winchester, 1972-1985. Winchester Museums, Winchester.

MannermaA, K. 2008: Archaeology of wings: Birds and people in the Baltic Sea region during the Stone Age. Unpublished Academic Dissertation, University of Helsinki.

Martin, L.; Edwards, Y. \& Garrard, A. 2013: Broad spectrum or specialised activity? Birds and tortoises at the Epipalaeolithic site of Wadi Jilat 22 in the eastern Jordan steppe. Antiquity 87(337): 649-665.

Matthews, J. \& Matthews, C. 1995: British and Irish Mythology. Diamond, London.

Meddens, B. 2002: Animal bones from Bainesse (Site 46). In: Wilson, P. (ed.): Cataractonium: Roman Catterick and its hinterland, excavations and research, 1958-1997: 419-425. CBA Research Report 128. York.
Moreno-Garcia, M. \& Pimenta, C. 2010: Beyond chicken: avian biodiversity in a Portuguese late medieval urban site. In: Prummel, W.; Zeiler, J. \& Brinkhuizen, D. (eds.): Birds in Archaeology: Proceedings of the $6^{\text {th }}$ Meeting of the ICAZ Bird Working Group: 261-276. Barkhuis, Groningen.

Morris, J. \& Jervis, B. 2011: What's so special? A reinterpretation of Anglo-Saxon 'special deposits'. Medieval Archaeology 55: 66-81.

Mulkeen, S. \& O’Connor, T. 1997: Raptors in towns: Towards an ecological model. International Journal of Osteoarchaeology 7: 440-449.

O'Connor, T. 1989: Bones from Anglo-Scandinavian Levels at 16-22 Coppergate. 15/3. The Archaeology of York. Council for British Archaeology. London.

- 1993: Bird bones. In: Casey, P.: Davies, J.; Evans, J. \& Allason-Jones, L. (eds.): Excavations at Segontium (Caernarfon) Roman Fort, 1975-1979: 119. CBA Research Report 90 . York.

OGgIns, R. 2004: The Kings and Their Hawks: Falconry in Medieval England. Yale University Press, London.

Ostrowski, S. 2006: A rare case of golden eagle (Aquila chrysaetos) destruction for use in traditional medicine, Wakhan, Afghanistan. Wildlife Conservation Society Unpublished report.

PARKER, A. 1988: The birds of Roman Britain. Oxford Journal of Archaeology 7(2): 197-226.

PITTs, M. 2006: Flight of the eagles. British Archaeology 86: 6.

Platt, M. 1936: Report on the animal bones found in the chambered cairn, Knowe of Ramsay, Rousay, Orkney. Proceedings of the Society of Antiquarians of Scotland 70: 415-419.

Powell, A. \& Clark, K. 2002: The animal bone. In: Foreman, S.; Hiller, J. \& Petts, D. (eds.): Gathering the People, Settling the Land: The Archaeology of a Middle Thames Landscape: Anglo-Saxon to Post-Medieval: 44-49. Thames Valley Landscapes 14. Oxford. + CD ROM.

RACKHAM, P. 1995: The animal bone from post-roman contexts. In: Phillips, D. \& B. Heywood (eds.): Excavations at York Minster Volume 2: the finds: 533-558. HMSO, London.

Radovčić, D.; SrŠEn, A.O.; RadovČIĆ, J. \& Frayer, D.W. 2015: Evidence for Neandertal jewelry: modified white-tailed eagle claws at Krapina. PLoS One 10(3): e0119802.

Rainsford, C.; O'Connor, T. \& Connelly, P. 2016: The embarrassment of riches: rationalising faunal assemblages from large urban sites. International Journal of Osteoarchaeology 26: 221-231. 
RaJKovaCa forthcoming: Animal bones. In: Evans, C.; Lucy, S. \& Patten, R. (eds.): Riversides: Neolithic Barrows, a Beaker Grave, Iron Age and Anglo-Saxon burials and Settlement at Trumpington, Cambridge. Oxbow books, Oxford.

Romandini, M.; Peresani, M.; Laroulandie, V.; Metz, L.; Pastoors, A.; Vaquero, M. \& Slimak, L. 2014: Convergent evidence of eagle talons used by late $\mathrm{Ne}$ anderthals in Europe: a further assessment on symbolism. PloS one 9(7): e101278.

Schulting, R.J. \& Richards, M.P. 2002: The wet, the wild and the domesticated: the Mesolithic-Neolithic transition on the west coast of Scotland. European Journal of Archaeology 5(2): 147-189.

SerJeantson, D. 2009: Birds. Cambridge University Press, Cambridge.

- 2010: Extinct birds. In: O’Connor, T. \& Sykes, N. (eds.): Extinctions and Invasions: A Social History of British Fauna:146-155. Windgather, Oxford.

- 2011: Review of Animal Remains from the Neolithic and Early Bronze Age of Southern Britain (400 BC - 1500 BC) 29-2011. English Heritage Research Department Report Series, London.

- 2014: Survey of animal remains from southern Britain finds no evidence for continuity from the Mesolithic period. Environmental Archaeology 19(3): 256262.

SerJeAntson, D. \& Morris, J. 2011: Ravens and crows in Iron Age and Roman Britain. Oxford Journal of Archaeology 30(1): 85-107.

Sмiтн, C. 1997: Animal bone. In: Moloney, C. \& Coleman, R. (eds.): The development of a medieval street frontage: the evidence from excavations at 80-86 High Street, Perth: 767-773. Proceedings of the Society of Antiquaries of Scotland 127: 707-782.

- 2000: Animal bone. In: Perry, D. (ed.): Castle Park, Dunbar: 2000 Years of a Fortified Headland: 194297. Society of Antiquaries of Scotland, Edinburgh.

- 2012: Bird Bone. In: Johnson, M. \& Cameron, K. (eds.): An early Bronze Age unenclosed cremation cemetery and Mesolithic pit at Skilmafilly, near Maud, Aberdeenshire: 30-31. Scottish Archaeological Internet Report 53.

Smith, C. \& Clarke, A. 2011: The bird bone. In: Hodgson, G. (ed.): The Perth High Street Archaeological Excavation 1975-77. Living and Working in a Medieval Scottish Burgh. Environmental Remains and Miscellaneous Finds: 53-58. Perth, Tayside and Fife Archaeological Committee 4.
Soma, T. 2012: Contemporary falconry. In: Altai-Kazakh in Western Mongolia. The International Journal of Intangible Heritage vol 7: 103-111.

SPIKINS, P. 2008: Mesolithic Europe: glimpses of another world. In: Spikins, P. \& Bailey, G.N. (eds.): Mesolithic Europe: 1-17. Cambridge University Press, Cambridge.

Stallibrass, S. 1996: Animal bones. In: Jackson, R. \& Potter, T. (eds.): Excavations at Stonea, Cambridgeshire 1980-85: 587-612. British Museum Press, London.

Stelfox,A. 1938: The birds of Lagore about one thousand years ago. The Irish Naturalists' Journal 7(2): 37-43.

Stokes, P. 2000: A cut above the rest? Officers and men at South Shields Roman fort. In: Rowley-Conwy, P. (ed.): Animal Bones, Human Societies: 145-151. Oxbow Books, Oxford.

Storms, G. 1948: Anglo-Saxon Magic. Martinus Nijhoff, The Hague.

Sykes, N. 2014: Beastly Questions: Animal Answers to Archaeological Issues. Bloomsbury, London.

Thompson, A.; Westman, A. \& Dyson, T. (eds.) 1998: Archaeology in Greater London 1965 - 1990: A Guide to Records of Excavations by the Museum of London. The Archaeological Gazetteer Series, Volume 2. Museum of London, London.

VAN WiJNGAARden-BAKKeR, L. 1985: Birds. In: Woodman, P. (ed.): Excavations at Mount Sandel, 1973-77, County Londonderry. HM Stationery Office, London.

Watson, J. 2010: The Golden Eagle. Bloomsbury, London.

White, T. 1960: The Book of Beasts: Being a Translation from a Latin Bestiary of the Twelfth Century. Parallel Press, Madison.

Wilson, B.; Wheeler, A.; Bramwell, D.; Harcourt, R. \& ARmitage, P. 1986: Faunal remains: animal bones and shells. In: Miles, D. (ed.): Archaeology at Barton Court Farm, Abingdon, Oxfordshire. CBA Research Report 50: Fiche 8, A1-G14. Oxford.

Woodward, A. \& Leach, P. 1993: The Uley Shrines. English Heritage/British Museum Press, London.

YALDEN, D.W. 2002: Place name and archaeological evidence on the recent history of birds. Acta Zoologica Cracoviensia 45: 415-429.

- 2007: The older history of the White-tailed Eagle in Britain. British Birds 100(8): 471-480.

Yalden, D.W. \& Albarella, U. 2009: The History of British Birds. Oxford University Press, Oxford. 
APPENDIX 1: LATIN NAMES OF ALL TAXA REFERRED TO IN THE TEXT TABLES

\begin{tabular}{ll}
\hline Common Name & Latin Name \\
\hline Barnacle goose & Branta leucopsis \\
Beaver & Castor fiber \\
Buzzard & Buteo buteo \\
Cat & Felis catus \\
Cattle & Bos taurus \\
Crane & Gruidae \\
Dog & Canis familiaris \\
Goat & Capra hircus \\
Golden eagle & Aquila chrysaetos \\
Goshawk & Accipiter gentilis \\
Grouse & Lagopus or Tetratao \\
Hare & Lepus europaeus \\
Horse & Equus caballus \\
Peafowl & Pavo cristatus \\
Rabbit & Oryctolagus cuniculus \\
Raven & Corvus corax \\
Red deer & Cervus elaphus \\
Red kite & Milvus milvus \\
Red-throated diver & Gavia stellata \\
Reindeer & Rangifer tarandus \\
Sheep & Ovis ares \\
Sparrowhawk & Accipiter nisus \\
White-tailed eagle & Haliaeetus albicilla \\
Wild boar/ pig & Sus scrofa \\
Wolf & Canis lupus \\
\hline & \\
\hline &
\end{tabular}


